\title{
The Effect of Sports on the Phenomenon of Baby Blues Syndrome (Postpartum Blues) in Postpartum Mothers
}

\author{
Ema Novita Deniati \\ Faculty of Sport Science, \\ Universitas Negeri Malang \\ Malang,
}

\author{
$2^{\text {nd }}$ Annisaa \\ Faculty of Medicine \\ Sebelas Maret University
}

Surakarta

\author{
$3^{\text {rd }}$ Selvia Agnesfadia \\ Faculty of Medicine \\ Sebelas Maret University
}

Surakarta

ema.deniati.fik@um.ac.id

\begin{abstract}
Purpose: baby blues syndrome often occurs in postpartum mothers. The prevalence of baby blues syndrome worldwide according to WHO is around $3 \%$ to $8 \%$. In Asia, cases of baby blues syndrome are still very high. In Indonesia, it will increase to $70-80 \%$ in 2020. The incidence of baby blues syndrome can be prevented and overcome by intervention in the form of exercise; 2) Methods: this study uses literature studies from articles indexed by google scholars and pubmed with the keywords sports, baby blues, postpartum, depression in order to obtain $\mathbf{1 0}$ quantitative research articles; 3) Results: several research articles stated that exercise was able to overcome postpartum depression or baby blues syndrome with an intervention time of about 4-8 months as measured using the EPDS questionnaire; 4) Conclusion: exercise with light to moderate intensity can prevent symptoms of depression and is safe for mothers and babies.
\end{abstract}

Keywords- Exercise, Baby Blues, Postpartum, Psychological, Mother

\section{INTRODUCTION}

The postpartum period in the mother starts from the birth of the placenta until the uterus returns to its pre-pregnancy condition. The puerperal period lasts for about 6 weeks, i.e. the delivery of the placenta to 42 days after delivery [1]. After giving birth, the mother will undergo several adaptation phases such as the taking in phase, taking hold phase, and letting go phase [2]. The taking-in phase is a dependency phase that takes place on the first and second day after delivery. Mothers will focus on themselves, tend to be passive in their surroundings and increase appetite. Furthermore, the taking hold phase is where the mother feels worried because she is unable to take care of the baby and is easily irritated so that in this phase postpartum depression often occurs. This phase lasts from the third to tenth day after delivery. The last phase is the letting go phase which takes place after 10 days of delivery where at this phase the mother will accept new responsibilities and roles as a mother for the baby she is born with. If in this phase the mother cannot go through the psychological adaptation process properly, then a mother has a high probability of experiencing Baby Blues Syndrome.

WHO (2018) noted the prevalence of postpartum blues in general in the world population is $3-8 \%$ with $50 \%$ of cases occurring in productive ages, namely 20-50 years. WHO also states that this postpartum blues disorder affects about $20 \%$ of women and $12 \%$ of men at some time in life [3]. The incidence of baby blues or postpartum blues in Asia is quite high and varies between $26-85 \%$, while in Indonesia the incidence of baby blues or postpartum blues is between $50-70 \%$ of postpartum women [1]. In Indonesia, the incidence rate will increase in 2020 to around $70-80 \%$ of postpartum mothers experiencing baby blues syndrome and around $10-13 \%$ of them continue to have postnatal depression [4]-[7].

Baby blues syndrome is a mild emotional stability disorder in the mother as a result of the adjustment process for the birth of the baby which takes place within a few hours to about two weeks with the peak of instability occurring on days 3-5 [8]. Emotional instability in postpartum mothers who experience baby blues syndrome triggers mothers to be irritable, feel excessively worried, feel unable to perform their duties as a good mother, and at a severe level of disturbance can make the mother indifferent and even abuse their biological child. [9]. The phenomenon of Baby Blues Syndrome can be caused by tiredness of 
taking care of the baby, fatigue during the delivery process, hormonal changes that go up and down quickly, excessive anxiety and worries about not being able to take care of the baby alone [10].

Baby Blues Syndrome as a mild emotional disorder can be prevented and minimized the risk with physical activity. Interventions in the form of exercise function to restore health conditions, accelerate healing, restore, improve muscle tension after pregnancy, especially in the muscles of the back, pelvic floor, and abdomen and prevent complications
[11]. In addition, the positive effect of regular physical activity in relieving depressive disorders was explained using several mechanisms [12]. Exercise increases the concentration of neurotransmitters such as 5HT, dopamine, and noradrenaline. In addition, physical activity increases the secretion of BDNF (a neurotic factor produced in the brain), the concentration of which is low in people with depression [13]. A meta-analysis conducted by McCurdy et al. showed that light or moderate physical activity effectively reduced depressive disorder symptoms in women in the postpartum period [14].

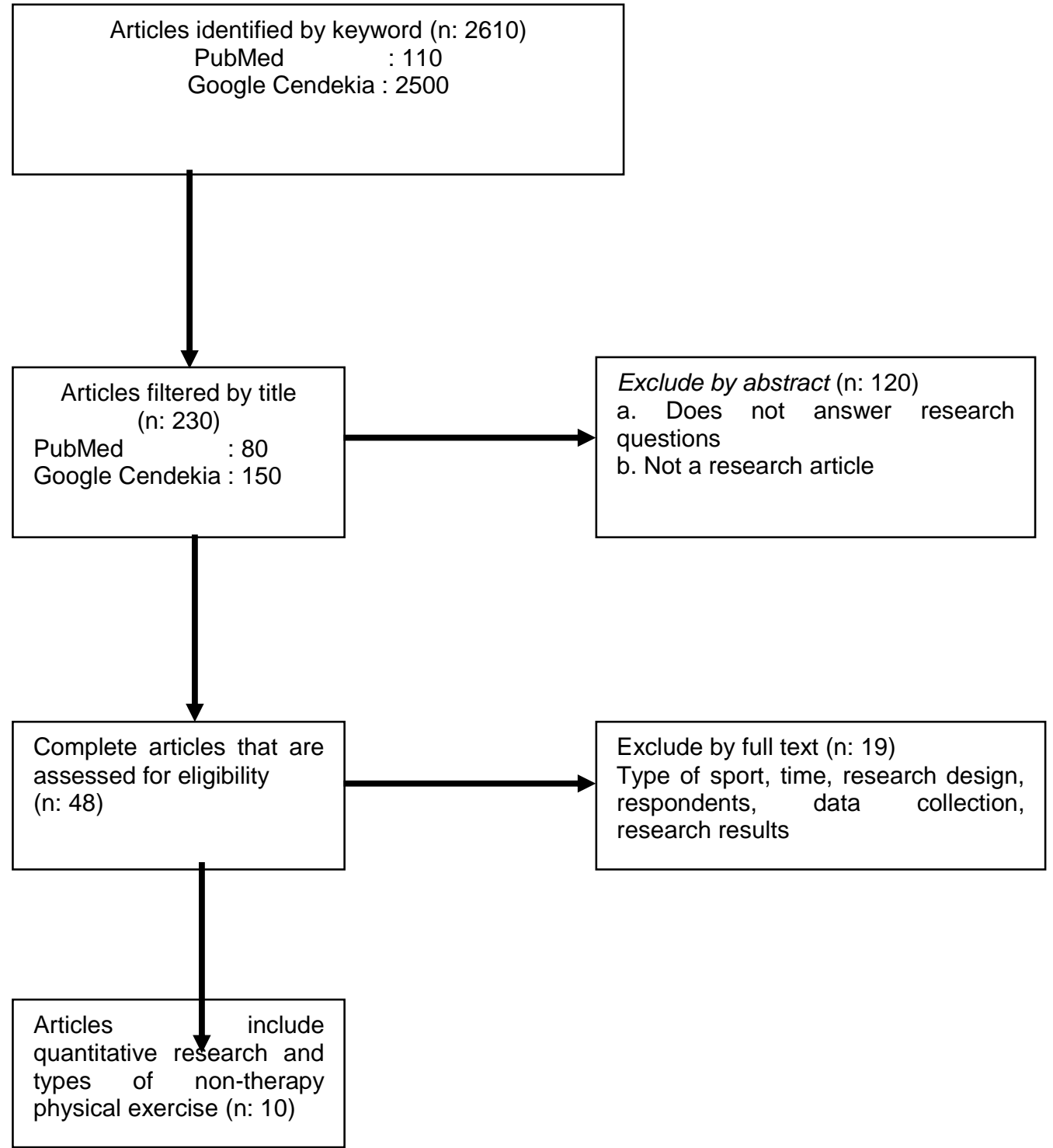

\section{FIGURE 1. PRISMA FLOWCHART OF RESEARCH DATA EXTRACTION}

\section{METHOD}

\section{A. Data Source}

This study uses a literature study method taken from scientific databases indexed by Google Scholar and PubMed. The literature in this study is an article on the results of primary quantitative research conducted from 2011 to 2021 which contains research on the effect of exercise on postpartum mothers who experience the baby blues syndrome. This study uses several keywords to search for relevant literature such 
as exercise, baby blues syndrome, postpartum blues, mothers giving birth, postpartum, and postpartum mothers. Next, a list of related articles will appear which will be further selected.

\section{B. Data Extraction}

The search and data extraction strategy in this study used the PRISMA flow chart (figure 1) [15]. The total search results of research articles based on keywords, obtained as many as 2610 articles. Then the articles that have been identified based on the titles are 230 articles. Furthermore, the entire article is identified as the abstract section. Articles that did not answer the research question and did not include research articles were excluded for the next stage so that 120 articles were obtained. The remaining articles are then identified as a whole such as the author's name, type of sport, research time, research design, data collection method, research respondent selection, number of respondents, and research results. So that 19 articles were obtained that were appropriate and relevant to the research, but 4 articles that were included in qualitative research were not used in this study. Therefore, at the final stage there were only 15 quantitative research articles for review.

\section{RESULT AND DISCUSSION}

\section{A. RESULT}

After selecting articles using the PRISMA flowchart method, 10 quantitative research articles were obtained that were published from 2011 to 2021 (table 1). Research articles on the effect of exercise on baby blues syndrome or postpartum depression are scattered in various countries. According to the article search results that have been carried out, there are several countries such as Indonesia $(n=1)$, Iran $(n=1)$, Japan $(\mathrm{n}=1)$, India $(\mathrm{n}=1)$, United States $(\mathrm{n}=1)$, Brazil ( $\mathrm{n}=1)$, Spanish $(\mathrm{n}=1)$, Norwegian $(\mathrm{n}=2)$, and English $(n=1)$. The research was conducted using three types of research designs, namely randomized controlled studies $(n=4)$, cohort studies $(n=5)$, and quasiexperimental studies $(\mathrm{n}=1)$.

\subsubsection{Types of Exercise in Baby Blues Syndrome}

Sports exercises carried out in the prenatal period are able to prevent the occurrence of postpartum blues or baby blues syndrome. These exercises include Qigong movement exercises that focus on slow body movements and body balance with a combination of subtle breathing techniques, so as to reduce stress levels associated with the psychological condition of the mother after giving birth [16]. The sports concept in the form of Low, Moderate to Virgous Physical Activity was chosen as an intervention in the study $(n=5)$. The concept is the provision of physical exercise with different intensity levels based on international physical activity guidelines which are categorized into low intensity with Metabolic Equivalent (MET) $<600$ minutes/week, moderate or moderate intensity with MET 600-2999 minutes/week, and high intensity with MET. 3000 minutes/week [17]-[21].

Other variations of exercise training applied were aerobic exercise $(n=2)$ and group training with instructors $(n=2)$. In the study of Carolina de Vargas Nunes Coll et al (2019), aerobic and endurance exercise for 16 weeks did not have a significant effect on maternal postpartum depression [22]. Meanwhile, the study by Araceli Navas et al (2021) in Spain that used an intervention in the form of aquatic aerobic exercise stated that the intervention group did not report postpartum anxiety or depression [23]. In a study conducted by Kristian M Songoygard et al (2011) who was guided by a physiotherapist for 12 weeks stated that there was no significant difference according to the respondents' EPDS scores [24]. However, another study conducted by Amanda $\mathbf{J}$ Daley et al (2012) using an intervention in the form of group exercise training accompanied by an instructor with a longer intervention time of 6 months stated that exercise was effective for treating postpartum depression [25].

\subsubsection{Instruments for Measuring the Effectiveness of Exercise in Baby Blues Syndrome}

To obtain research data, almost all studies used the Edinburgh Postnatal Depression Scale (EPDS) questionnaire $(n=9)$ but there were several studies using other questionnaires. The questionnaires included demographic characteristics and physical activity $(\mathrm{n}=1)$, Psychological General Well-Being Index (PGWBI) $(\mathrm{n}=1)$, Physical Activity Level $(\mathrm{n}=1)$, Kessler Psychological Distress Scale $(n=1)$, International Physical Activity Questionnaire (IPAQ), EQ-5D. The EPDS is a 10-item questionnaire that was developed to identify women with postpartum depression with various symptoms of clinical depression such as feelings of guilt, sleep disturbances, anhedonia, fatigue, and even suicidal 
ideation [26]. EPDS can be used after one month postpartum to 8 months postpartum to detect the presence of postpartum depression in the mother.

\subsubsection{Characteristics of Pregnant Women Who Received Intervention}

This research is a research that requires a long time. This is because this study does not only focus on postnatal events but also on maternal prenatal activities. There are 8 studies involving the prenatal period and 2 other studies only examining the postnatal period of the mother. Pregnant women who are respondents are women who check their pregnancy and postnatal conditions in the same place. They were then given an intervention at a gestation period between 14-36 weeks. In addition, women who are respondents in the study are women who do not have contraindications such as hypertension, diabetes, and obesity because they can be confounding variables. Mother's compliance in doing sports exercises that have been determined also affects.

\section{B. DISCUSSION}

In this study, the article used is a research article that discusses the effect of exercise on the incidence of postpartum depression or baby blues syndrome. In Kristian's research in 2011 stated that there was no significant difference in EPDS scores between women who did regular exercise and women in the control group with 3 times of data collection so that the EPDS scores were $10 \quad(p=0.46), 13 \quad(p=0.25)$, and 10 $(\mathrm{p}=0.03)$. Furthermore, in 2012, research by Amanda $\mathrm{J}$ Daley stated that there is a relationship between exercise and postnatal depression so that exercise is effective for treating postnatal depression.

Research conducted by Zewditu Demissie, (2013) stated that there was no significant relationship between total MVPA during pregnancy and symptoms of postpartum depression. However, there was a decrease in postpartum depression symptoms found in pregnant women who did MVPA exercises at 17-22 weeks of gestation. While research by Parvin Bahadoran, (2014) showed that $74.7 \%(\mathrm{n}=68)$ subjects had light physical activity and $25.3 \%$ ( $\mathrm{n}=$ 23) had moderate and heavy physical activity. The results of this study stated that there was no significant difference between the two groups of physical activity. The mean score of maternal wellbeing in the light physical activity group was lower than in the moderate and strenuous activity group.
In 2019, there were 3 studies from Indonesia, Norway and Brazil. The results of research in Indonesia by Jehan Puspasari and Dian Fitria showed that there was an effect between qigong exercise intervention and prevention of postpartum depression symptoms in adolescent mothers with a $p$ value of 0.000 . In a study in Norway stated that there was no difference in EPDS between the group given the exercise 2.96 and the control group $3.48(\mathrm{p}=0.55)$. So there was no effect between exercise during pregnancy and postpartum depression. And the results of a study in Brazil by Carolina de Vargas Nunes stated that there was no significant difference in the mean score for postpartum depression between the intervention group and the control group. There was also no significant difference in the rate of postpartum depression between the intervention group and the control group.

However, a recent study in 2020 and 2021 stated that women with light activity only had lower psychological distress during pregnancy than those who did not do physical activity, low physical activity during pregnancy had a 2.3 times chance of experiencing depression. postpartum and were 3.15 times more likely to experience postpartum blues in obese, hypertensive, and diabetic mothers, and women in the intervention group were less likely to report anxiety or depression on the EQ5D and had a lower mean EPDS score $(6.1 \pm 1.9$ vs. $6.8 \pm 2.4$, p < $0.010)$. 


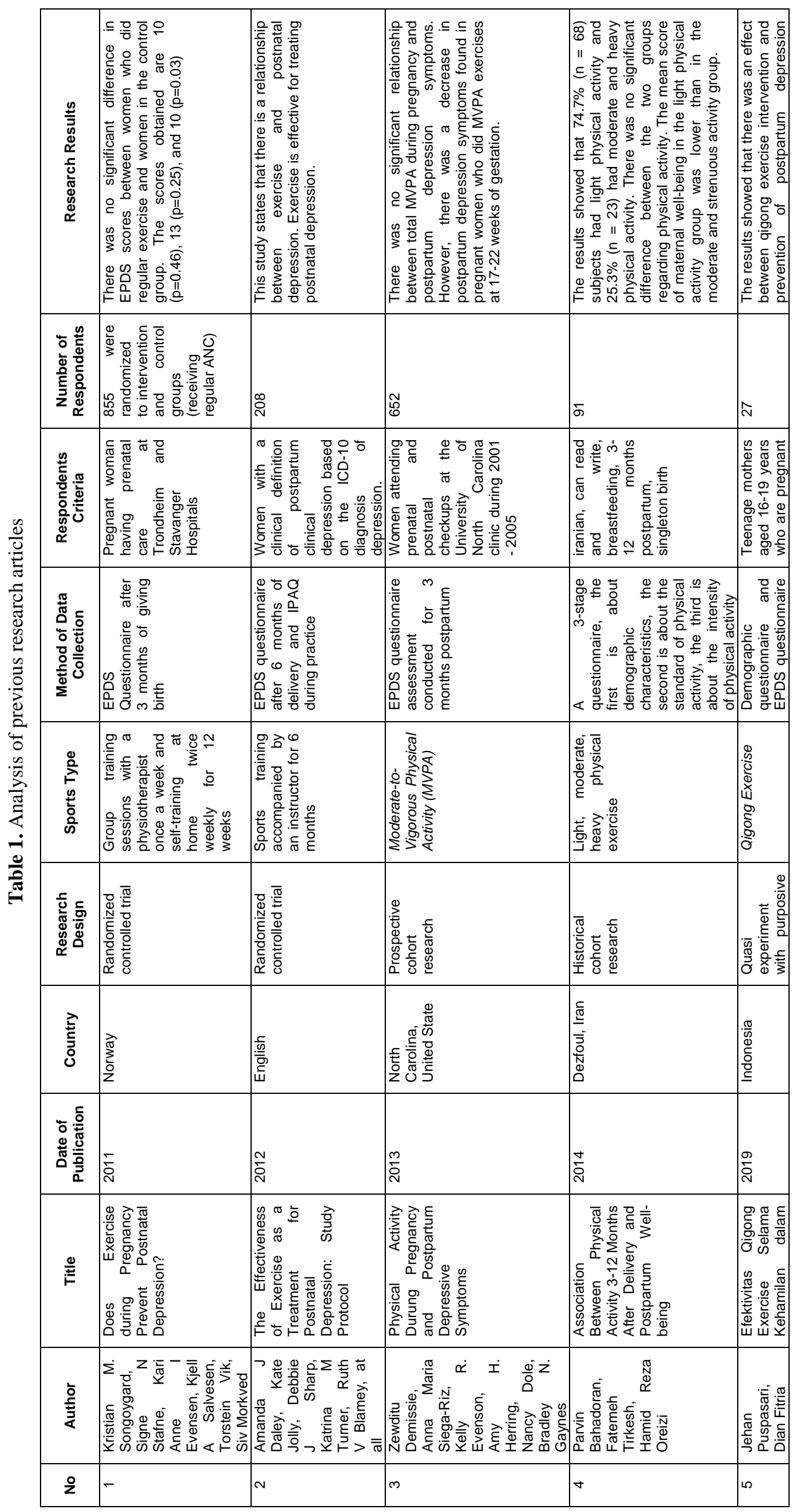




\begin{tabular}{|c|c|c|c|}
\hline 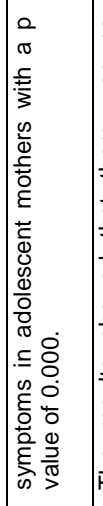 & 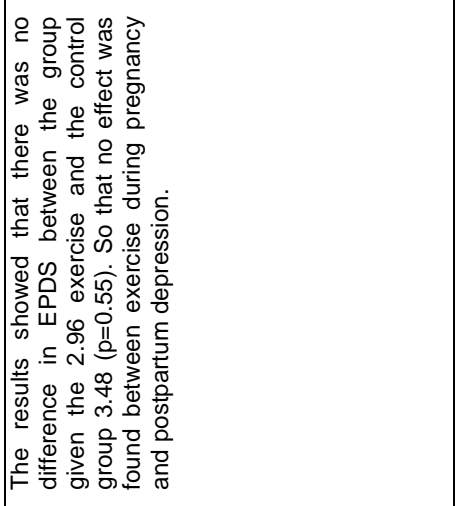 & 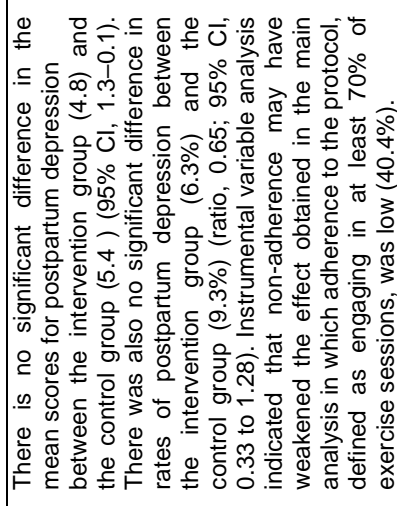 & 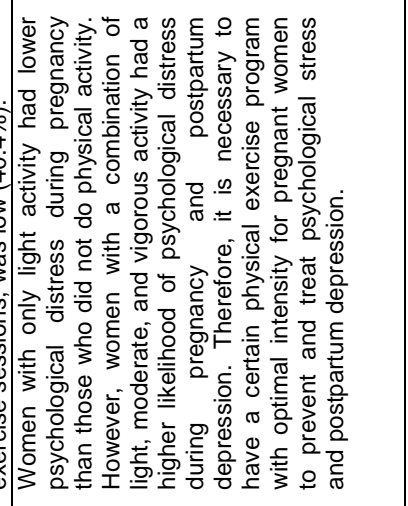 \\
\hline & б̆ & 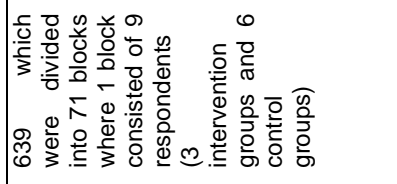 & 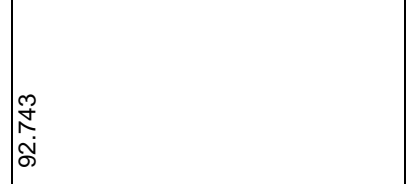 \\
\hline 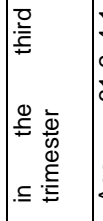 & 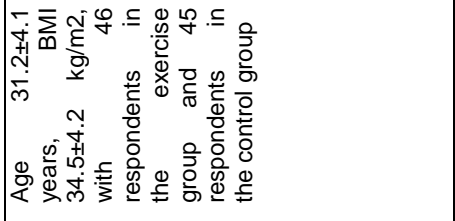 & 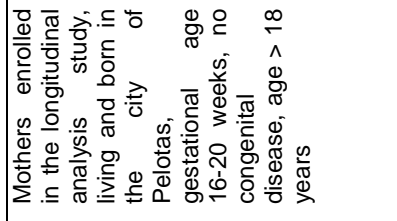 & 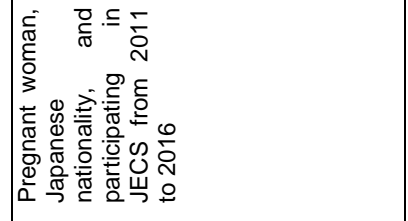 \\
\hline 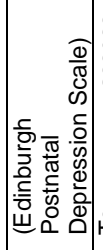 & 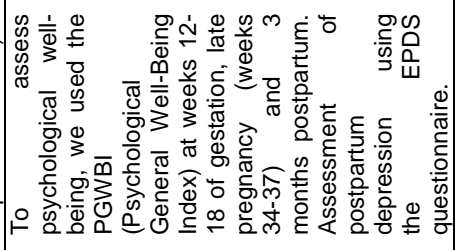 & 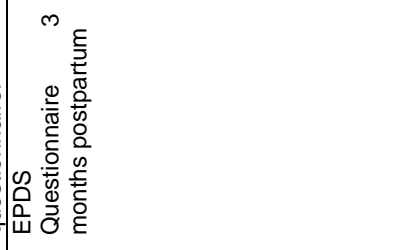 & 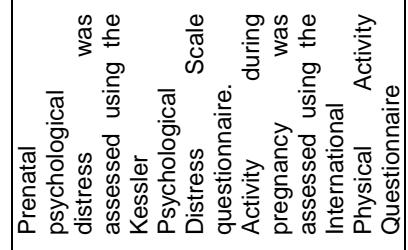 \\
\hline & 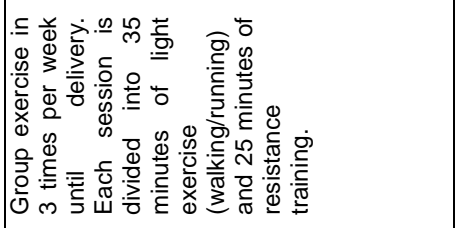 & 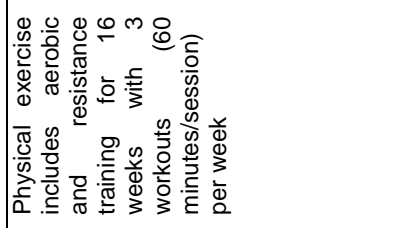 & 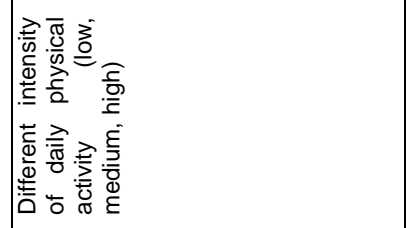 \\
\hline 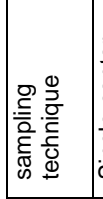 & 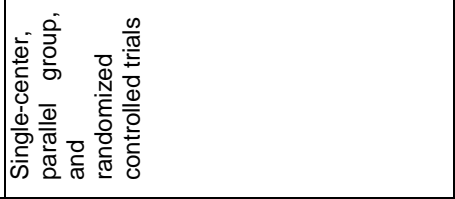 & 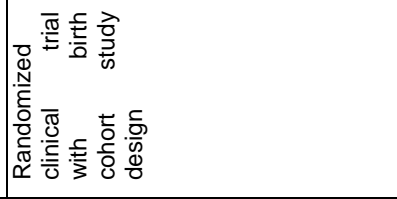 & 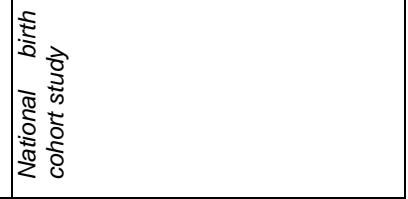 \\
\hline & 离 & \begin{tabular}{|l}
$\overline{\overline{\widetilde{N}}}$ \\
$\frac{\tilde{\omega}}{2}$
\end{tabular} & 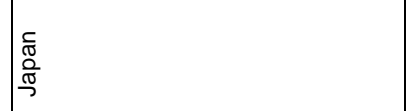 \\
\hline & i্ & 啇 & 命 \\
\hline 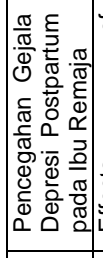 & 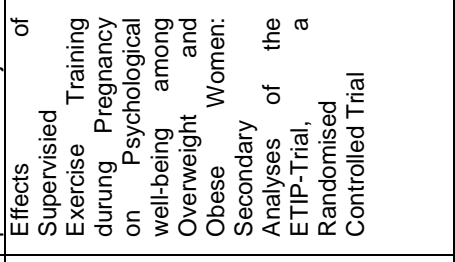 & 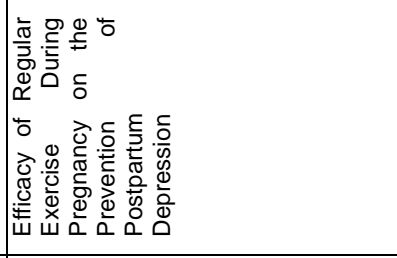 & 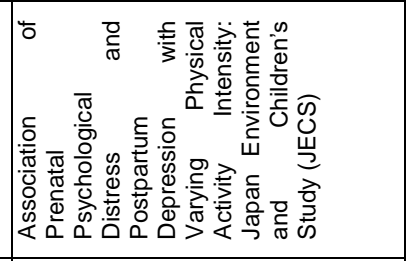 \\
\hline & 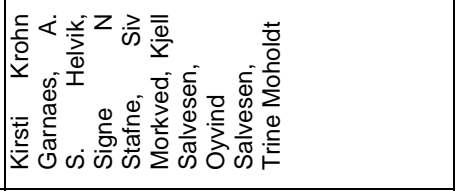 & 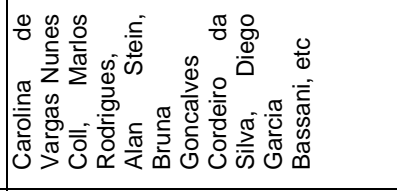 & 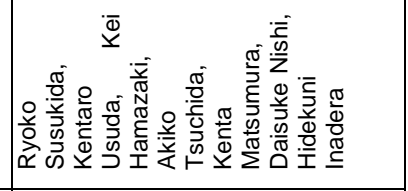 \\
\hline & 0 & $\wedge$ & $\infty$ \\
\hline
\end{tabular}




\begin{tabular}{|c|c|c|}
\hline & 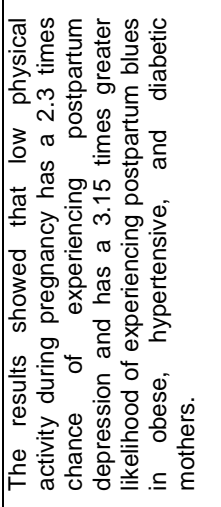 & 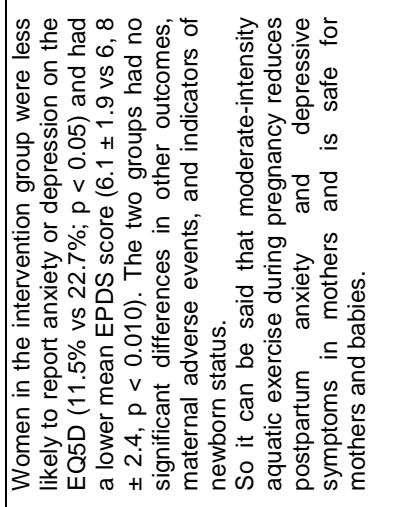 \\
\hline & 号 & 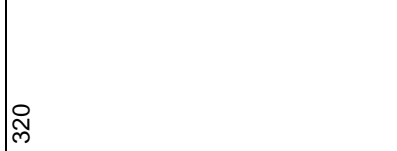 \\
\hline & 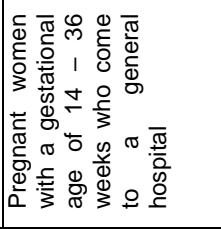 & 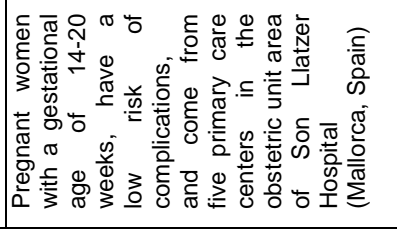 \\
\hline 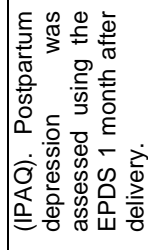 & 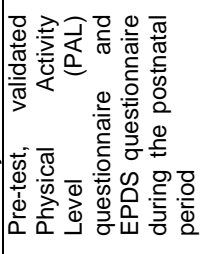 & 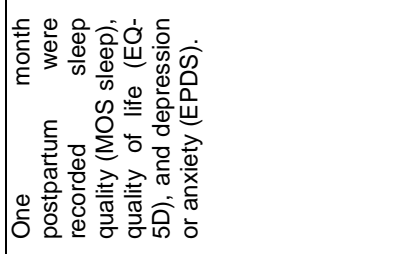 \\
\hline & 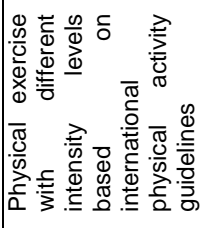 & 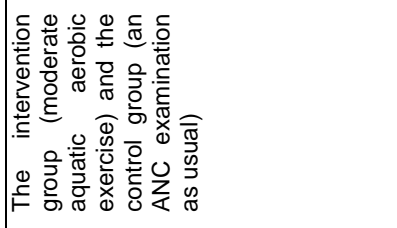 \\
\hline & $\begin{array}{l}\frac{3}{2} \\
\frac{2}{0} \\
\text { to } \\
\frac{0}{0} \\
\frac{0}{0} \\
0\end{array}$ & 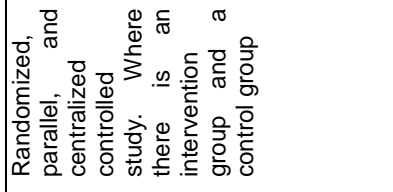 \\
\hline & 粟 & 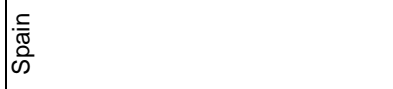 \\
\hline & ¿্ّ & ָิ๊ \\
\hline & 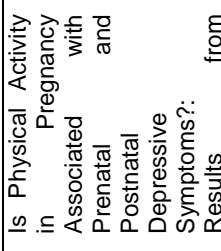 & 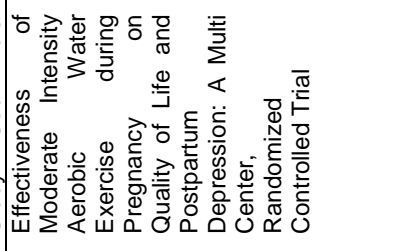 \\
\hline & 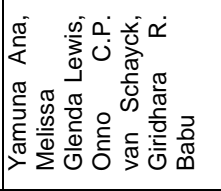 & 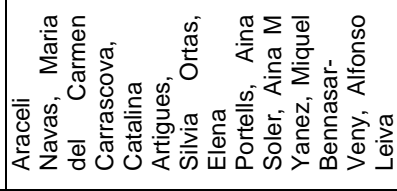 \\
\hline & $\sigma$ & $\stackrel{\circ}{\circ}$ \\
\hline
\end{tabular}




\section{CONCLUSION}

Baby Blues Syndrome as a mild emotional disorder can be prevented and minimized the risk with physical activity. Physical exercise with light to moderate intensity during pregnancy reduces postpartum anxiety and depressive symptoms in the mother and is safe for both mother and baby

\section{REFERENCES}

[1] L. W. Susanti and A. Sulistiyanti, "Analisis Faktor-Faktor Penyebab Terjadinya Baby Blues Syndrom Pada Ibu Nifas," Infokes, vol. 7, no. 2, pp. 12-20, 2017, [Online]. Available: https://docplayer.info/90726038-Analisisfaktor-faktor-penyebab-terjadinya-babyblues-syndrom-pada-ibu-nifas.html.

[2] P. T. Rahayu, "Pengalaman Baby Blues," Universitas Muhammadiyah purwokerto, 2010.

[3] R. N. Raharjo, "Pertanggungjawaban Pidana Ibu Baby Blues Syndrome Yang Melakukan Tindak Pidana Penganiayaan Anak," Universitas Airlangga, 2020.

[4] M. Nareza, "Kenali Penyebab Baby Blues dan Cara Mengatasinya," alodokter.com, 2020. https://www.alodokter.com/kenali-penyebabbaby-blues-dan-cara-mengatasinya.

[5] M. Nareza, "Memahami Perbedaan Baby Blues Syndrome dan Depresi Pasca Melahirkan," alodokter.com, 2020. https://www.alodokter.com/memahamiperbedaan-baby-blues-syndrome-dan-depresipasca-melahirkan.

[6] E. Pranita, "Alami Baby Blues Setelah Melahirkan, Ini Bedanya dengan Depresi Postpartum dan Gangguan Kecemasan," kompas.com, 2021.

https://www.kompas.com/sains/read/2021/03/ 09/200500223/alami-baby-blues-setelahmelahirkan-ini-bedanya-dengan-depresipostpartum?page=all.

[7] C. S. Pratiwi, "Seperempat ibu depresi setelah melahirkan, tapi penanganannya belum optimal. Mengapa?," theconversation.com, 2019.

https://theconversation.com/seperempat-ibudepresi-setelah-melahirkan-tapipenanganannya-belum-optimal-mengapa117205.

[8] D. Fatmawati, "Faktor Risiko Yang Berpengaruh Terhadap Kejadian Postpartum
Blues," J. EduHealth, vol. 5, no. 2, p. 244985, 2015.

[9] I. Oktiriani, "Perilaku Baby Blues Syndrome Pada Ibu Pasca Melahirkan Di Kelurahan Sekaran, Kecamatan Gunung Pati," Semarang, 2017.

[10] S. Suryati, "the Baby Blues and Postnatal Depression," J. Kesehat. Masy., vol. 2, no. 2, p. 191, 2008, doi: 10.24893/jkma.2.2.191193.2008.

[11] S. I. V. S. I. Victoria and J. S. Y. J. S. Yanti, "ASUHAN KEBIDANAN PADA IBU NIFAS DENGAN PELAKSANAAN SENAM NIFAS," J. Kebidanan Terkini, vol. 1, no. 1, pp. 45-55, 2021.

[12] I. Oktiriani, "Perilaku baby blues syndrome pada ibu pasca melahirkan di Kelurahan Sekaran, Kecamatan Gunung Pati," Universitas Negeri Semarang, 2017.

[13] D. Kołomańska-Bogucka and A. I. MazurBialy, "Physical activity and the occurrence of postnatal depression-a systematic review," Med., vol. 55, no. 9, 2019, doi: 10.3390/medicina55090560.

[14] T. McCurdy, S. D. Herrmann, R. G. McMurray, Y. Kim, E. A. Willis, and M. Kang, "The influence of physical characteristics on the resting energy expenditure of youth: A meta-analysis," Am. J. Hum. Biol., vol. 3, no. 29, 2017.

[15] S. P. Ratih and D. Susanna, "Perceived effectiveness of pictorial health warnings on changes in smoking behaviour in Asia: A literature review 11 Medical and Health Sciences 1117 Public Health and Health Services," BMC Public Health, vol. 18, no. 1, pp. 1-16, 2018, doi: 10.1186/s12889-0186072-7.

[16] J. Puspasari, "Efektifitas Qigong Exercise Selama Kehamilan dalam Pencegahan Gejala Depresi Post Partum pada Ibu Remaja," $J$. Kesehat. Holist., vol. 4, no. 1, pp. 27-33, 2020, doi: 10.33377/jkh.v4i1.67.

[17] P. Bahadoran, F. Tirkesh, and H. R. Oreizi, "Association between physical activity 3-12 months after delivery and postpartum wellbeing," Iran. J. Nurs. Midwifery Res., vol. 19, no. 1, pp. 82-87, 2014.

[18] Z. Demissie, A. M. Siega-Riz, K. R. Evenson, A. H. Herring, N. Dole, and B. N. Gaynes, "Associations between physical activity and postpartum depressive symptoms," $J$. Women's Heal., vol. 20, no. 7, pp. 10251034, 2011, doi: 10.1089/jwh.2010.2091. 
[19] K. K. Garnæs et al., "Effects of supervised exercise training during pregnancy on psychological well-being among overweight and obese women: Secondary analyses of the ETIP-trial, a randomised controlled trial," BMJ Open, vol. 9, no. 11, 2019, doi: 10.1136/bmjopen-2018-028252.

[20] R. Susukida et al., "Association of prenatal psychological distress and postpartum depression with varying physical activity intensity: Japan Environment and Children's Study (JECS)," Sci. Rep., vol. 10, no. 1, pp. 1-9, 2020, doi: 10.1038/s41598-020-63268-1.

[21] Y. Ana, M. G. Lewis, O. C. P. van Schayck, and G. R. Babu, "Is physical activity in pregnancy associated with prenatal and postnatal depressive symptoms?: Results from MAASTHI cohort study in South India," $J$. Psychosom. Res., vol. 144, p. 110390, 2021, doi: 10.1016/j.jpsychores.2021.110390.

[22] C. de V. N. Coll et al., "Efficacy of Regular Exercise During Pregnancy on the Prevention of Postpartum Depression: The PAMELA Randomized Clinical Trial," JAMA Netw. open, vol. 2, no. 1, p. e186861, 2019, doi: 10.1001/jamanetworkopen.2018.6861.

[23] A. Navas et al., "Effectiveness of ModerateIntensity Aerobic Water Exercise during Pregnancy on Quality of Life and Postpartum
Depression: A Multi-Center, Randomized Controlled Trial," J. Clin. Med., vol. 10, no. 11, p. 2432, 2021, doi: $10.3390 / \mathrm{jcm} 10112432$.

[24] K. M. Songøygard, S. N. Stafne, K. A. I. Evensen, K. A. Salvesen, T. Vik, and S. Mørkved, "Does exercise during pregnancy prevent postnatal depression?: A randomized controlled trial," Acta Obstet. Gynecol. Scand., vol. 91, no. 1, pp. 62-67, 2012, doi: 10.1111/j.1600-0412.2011.01262.x.

[25] A. J. Daley et al., "The effectiveness of exercise as a treatment for postnatal depression: study protocol," BMC Pregnancy Childbirth, vol. 12, 2012, doi: 10.1186/14712393-12-45.

[26] Wikipedia, "Edinburgh Postnatal Depression Scale," en.wikipedia.org, 2020. https://en.wikipedia.org/wiki/Edinburgh_Post natal_Depression_Scale. [9] A.

Pnueli, In transition from global to modular temporal reasoning about programs, in: K.R. Apt (Ed.), Logics and Models of Concurrent Systems, Springer, Berlin, Heidelberg, 1984, pp. 123-144.

DOI: https://doi.org/10.1007/978-3-642-82453-1_5 